\title{
Self-Regulation in the Learning Process: Actions through Self-Assessment Activities with Brazilian Students
}

\author{
Giovana Chimentão Punhagui ${ }^{1} \&$ Nadia Aparecida de Souza ${ }^{1}$ \\ ${ }^{1}$ Department of Education, State University of Londrina, Londrina, Brazil \\ Correspondence: Giovana Chimentão Punhagui, State University of Londrina, Londrina, Brazil. Tel: \\ 55-43-9151-8711. E-mail: giovana.punhagui@gmail.com
}

Received: August 19, 2013

Accepted: September 16, 2013 Online Published: September 26, 2013

doi:10.5539/ies.v6n10p47

URL: http://dx.doi.org/10.5539/ies.v6n10p47

\begin{abstract}
Learning a foreign language is, among other factors, based on the perception of one's own development and on undertaking strategies for greater communicative competence, which are founded in autonomous procedures that span the necessity for greater responsibility. As learning a language demands constant study, even after the school period - when there are no more teachers as mediators - the development of self-regulated learning skills becomes relevant. One option revealed in literature as a trigger for greater autonomy for learning, is the use of self-assessment. This study aimed at identifying and analyzing the potential of self-assessment for students to plan strategies and control their own actions, procedures which are part of self-regulated learning practice. The research adopted a qualitative approach in the form of a case study, and involved 25 students in the $8^{\text {th }}$ grade of a public school in Northern Paraná, Brazil. Information from the instruments for data collection was subjected to thematic content analysis. The results reveal that self-assessment encourages the use of strategic planning and monitoring of one's own learning only if joined to teacher intervention and motivational strategies.
\end{abstract}

Keywords: self-assessment, self-regulated learning, English language learning

\section{Introduction}

Self-regulated learning has been drawing the attention of researchers and people who are involved in the field of education, due to students' daily struggle to acquire competence and academic control. Lack of responsibility and manifestation of procrastination lead to low levels of learning and high levels of dissatisfaction and stress (Zimmerman, 2011). Therefore, studies have shown the importance of working with self-regulated processes in the classroom in order to increase students' ability to regulate their own learning significantly, supported positively and enduringly by their motivational beliefs and self-efficacy (Rosário et al., 2005; Sá, 2004; Stoeger \& Ziegler, 2011; Zimmerman \& Cleary, 2004).

From a social cognitive perspective, self-regulated learning is a process in which one acts proactively in monitoring his or her own thoughts, behavior and feelings, aiming to reach pre-established goals (Zimmerman, 2002). According to Zimmerman (2002, p. 66), "self-regulation is important because a major function of education is the development of lifelong learning skills". The author points out that, after the school period, young adults need to continue learning other skills which help them function better in social, professional and cultural contexts, among others. Beyond the school walls, self-regulation is fundamental for the progressive and constant adoption of: "flexible answers to the problems and obstacles they face, sustaining perceptions of efficacy in delays or deviations to what was planned previously without, however, losing sight of the established goals.” (Rosário et al., 2006, p. 81).

Despite the fact that children already recognize the importance of school activities to their learning from the age of ten (Sá, 2004), it seems that, over the years, students demonstrate less intrinsic pleasure in studying. However, elementary school teachers expect more independence from their students in relation to homework performance and length of study, thus delegating a greater quantity of activities from various subjects to be done at home. For this purpose, students need to have a good range of strategies and self-regulation skills, which generally doesn't happen in school reality. Most of the time, knowledge of self-regulation is poor, not allowing students to be aware of what and how to study in order to promote effective learning (Zimmerman \& Cleary, 2004).

Preadolescents and adolescents "show fragilities in establishing goals and in anticipating the consequences of 
many courses of action, being less capable of controlling distractive elements by themselves (Rosário et al., 2012, em fase de elaboração) (Note 1). Therefore, motivation and the execution of self-regulation processes are necessary in school education in order to better develop autonomy and independence.

Self-assessment is considered one of the options for motivating students' ability of reflection on their own learning, as well as the ability to learn how to learn (Boud, 1995). This evaluative tool is recognized as a pillar for the development of autonomy (Harris, 1997; Mistar, 2011).

The present study shows an investigative extract of a Master's study, and intends to answer the following research question: What are the limits and possibilities of the use of self-assessment for self-regulation of English language learning? At this time, the overall aim of the study is to identify and analyze the potential of self-assessment as a tool for promoting self-regulatory practices among students. For that, more specific aims were established:

- Analyze favorable aspects for reflection and reorganization of student work, considering the information found in the self-assessment activities;

- Identify and analyze the limits and possibilities of working with self-assessment in the classroom, intending self-regulation of learning;

- Analyze the potential of self-assessment on the effectiveness of self-reflection which is committed to overcome difficulties;

- Provide valuable information for the use of self-assessment in different educational contexts.

\section{Literature Review}

Self-regulated learning depends on the subject to be the agent of his or her own learning. After all, learning to develop one's self comes from a will, not from an obligation (Souza \& Boruchovitch, 2009). This regulation demands a continuous effort towards the acquisition of skills which facilitate the search for knowledge, since knowledge is fundamental for changing, but not sufficient. For this purpose, 'knowledge' and 'will' need to walk side by side so that we can move forward in the 'learning' direction." (Rosário et al., 2006, p. 87). It is not a personal characteristic that appears or lacks in students. It involves the selective use of processes chosen for each task (Zimmerman, 2002). The use of self-regulatory processes by the teacher in daily activities can offer opportunities and positive results for and by the students (Zimmerman \& Cleary, 2004).

According to Zimmerman (2002), self-regulatory interventions follow a cyclical model, which enhances the potential for someone to become autonomous. This cyclical model concerns three phases: the forethought phase, the performance phase, and the self-reflection phase.

To be considered self-regulated, an action needs a goal to be reached, a purpose for the effort undertaken in the performance of a task (Silva, 2004). Therefore, starting self-regulated learning education by self-reflecting - the third phase of Zimmerman's cyclical model (Zimmerman, 2002) - is advantageous (Stoeger \& Ziegler, 2011). According to the authors, conducting self-assessment and monitoring, supported by the use of standard material, can help students to recognize their strengths and weaknesses. This allows them to set appropriate goals to improve their learning and performance. The answers from the self-reflection phase are called reactions. In this phase, these reactions can take one of two forms: negative (defensive), resulting in the abandonment of the task, or positive (adaptive), which result in students persisting to reach the goal (Freire, 2009).

The students' increased awareness of their own learning can be achieved through instruction of strategy use. Self-regulated learning strategies are actions targeting the acquisition of information and/or skills that involve the individual being his or her own agent, clear goals and self-perceptions (Zimmerman \& Martinez-Pons, 1986). If students are aware of their responsibility for the selection, use and evaluation of learning strategies, there will be progress in knowledge and use of a foreign language (Cohen, 1998). After all, strategies are planning tools that students will need for the use of the language. Therefore, they cannot be applied without a purpose. Their choice should be based on a learning problem found or a difficulty that impedes learning (Little, 1996).

That's why one of the procedures discussed by Souza and Boruchovitch (2009), which is considered important for self-regulated learning, is the use of evaluative practices with a formative perspective, which focus on learning. These need to make it possible for the students to recognize their own strengths and weaknesses when tasks are performed, to check the quality of the work done and to think of ways to overcome their difficulties. Self-assessment is assumed to allow these actions to become real (Silva, 2004). A language learning process that seeks the continuity and development of competence and strategic control by students, could benefit from the use of self-assessment of learning (Little, 1996). The selection of strategies requires recognition of the demands and 
criteria of one's own learning in order to select those which meet one's needs (Duarte, 2004).

The habit of recording remedial action planning and improvement becomes a relevant strategy for the development of a foreign language because, in this way, students will be in constant touch with what they know and what they still need to overcome, guiding them for continuous studying. The use of strategies must be linked to daily activities in the classroom, so that teachers and students have opportunities to practice them (PARIS \& PARIS, 2001), making this process a habit.

Therefore, the validity of working with the recognition of one's own learning process, analysis of the strengths and difficulties, and especially strategies for the regulation of that which one still needs to overcome, is highlighted. Learning another language does not depend solely and only on the knowledge of its grammar rules and vocabulary, but requires the acquisition of communicative strategies that allow the exchange of messages with each other, enabling social relationships to occur. By providing self-assessment procedures, allowing students to monitor their learning, the teacher involves them in direct and progressive intervention, and that is where self-regulation plays a fundamental role.

Through self-observation, students have the opportunity to establish a connection between the results of their learning and the strategies they employed, enabling greater insight into the effectiveness of the actions undertaken (Stoeger \& Ziegler, 2011). This monitoring is necessary in so far as the process of self-regulation is not focused on the product, but in process analysis, guiding the redesign of actions aiming to bridge the gap between what is desired and what is achieved (Rosário et al., 2005).

However, most of the actions performed are not intrinsically motivated, especially after childhood, during which freedom is relatively limited by social pressure (Sá, 2004).

Losing themselves through watching TV or playing computer games, locked in their rooms, away from the eyes of their parents, some of our students are unable to control satisfaction impulses of immediate pleasure, filling their free time in a disorganized manner. In short or medium term, this dysfunction in the process of self-regulation, reflected in the low level of involvement in the completion of homework prescribed, and little or no daily study at home and hence bad grades, often lead young people to deny their own responsibility, blaming outside circumstances (e.g. the teacher; difficult tests) or attributing low school results to bad luck. (Rosário et al., 2012, n. p.)

Having specific difficulties in learning and not knowing how to study are factors in academic failure and can lead to passiveness, withdrawal and non-completion of tasks (Sá, 2004). Authors state the need for teachers' guidance in developing study habits (Freire, 2009; Rosário, 2001; Schunk \& Zimmerman, 1997), providing means for increasing motivation and sense of self-efficacy (Zimmerman, Bandura \& Martinez-Pons, 1992). The role of the teachers will be to guide students through ways that can help them overcome their weaknesses. Teachers will provide support for students to engage in activities and monitor their reflections, not allowing learning to become mere fulfillment of demands, but a reason to gather new experiences. "Our goal as educators should be oriented to help students connect their experiences at school, or elsewhere, with what they may come to realize." (Rosário et al., 2006).

The use of the reflective process creates conditions for cognitive motivation, that is, cognitively generated motivation which comes from the individuals themselves. Furthermore, aspiring patterns and self-efficacy perceptions influence the activities chosen and performed (Azzi \& Polydoro, 2010). For the performance of a task, students need to have positive motivational beliefs, an important factor of the forethought phase.

Thus, working with motivational factors in the classroom could be a powerful action taken by the teacher as they "are recommended to provoke interest in learning activities and, additionally, to break the monotony, to soften the mandatory nature of tasks, to combat boredom and to correct the sterility of certain contents." (Bzuneck, 2010, p. 23). Activities from "motivational factors" can be beneficial for learning because the intention is to cause an increase in the interest to perform a certain task. And keeping the interest is closely linked to the use of ways to promote the appreciation for learning (Bergin, 1999). There are some strategies for that, which depend on the teacher in order to be activated.

Students are able to develop mechanisms for regulating their own learning processes. Therefore, it is important to encourage them to learn by providing them with resources that activate their cognition and are demanding (Rosário et al., 2006). The encouragement to perform tasks at home is important, as it becomes a support for the development of better habits, better time management and self-direction (Xu, 2009).

Self-regulated students personally begin and direct their own efforts to acquire knowledge, detaching themselves from the dependence on others (Zimmerman, 1989). Learning, therefore, needs to involve the use of specific 
strategies so that goals are achieved.

\section{Method}

The exploration of the potential of self-assessment for the development of self-regulatory practices required constant presence in the study field, allowing direct contact with the context and the participants of the study. The research adopted a qualitative approach since it focused on discovering and developing grounded theory (Flick, 2004) through the analysis of concrete cases in their own context and time.

The strategy chosen was the use of a case study, allowing the description of a specific reality in detail, in order to know and understand it better, in search of new elements for new findings. The interpretative and subjective dimensions of educational aspects are further explored by methods of case study, allowing the researcher to plan, collect information and analyze them to reveal new experiences and answers to his questions. There is no manipulation of variables or artificial environments (Nunan, 2005), but capturing of daily circumstances in order to contribute to significant discoveries.

\subsection{Participants}

The study involved 25 students, aged 14 to 17 , from the $8^{\text {th }}$ grade of a public school in Northern Paraná, Brazil.

\subsection{Data Collection}

Data collection was performed between August and December of 2011, with 68 hours of intervention, which consisted of lesson planning with self-assessment activities and strategies, each lesson designed taking into account the results from each previous activity. All the self-assessment activities were designed using students' native language, Portuguese, because, as state Butler and Lee (2010), if the items of a self-assessment activity are prepared using students' first language, students can evaluate their performance more precisely, compared to when the items are written using the foreign language in study.

All the lessons were followed by the students' current teacher. Data was collected using (a) participant observation - description of the field, aiming to analyze and understand its meanings through the participants' perceptions and reactions; (b) document analysis - analysis of the strategic and self-assessment activities performed by the participants; (c) questionnaire - survey of the participants' perceptions of the self-assessment activities and possible changes in their study habits; (d) interview - deeper study of the information provided by the participants about the focus of the research.

\subsection{Data Analysis}

Data analysis was performed using thematic content analysis (Bardin, 1977). The data triangulation process was used due to the involvement of different sources of information and in order to increase the validity of the study. For this study, we chose a thematic analysis, which is derived from the categorical analysis technique, dividing the content into themes, ie fragments that correspond to a particular idea.

The initial hypothesis was that the proposition of self-assessment activities - focused on reflection and not on self-grading - generate a commitment to self-management of learning difficulties by the student. The function of content analysis, therefore, was to administrate evidence, taking the hypothesis as a guideline for the implementation of systematic analysis.

We opted for the thematic analysis using indicators of semantic nature, individualized reporting units linked by themes. We used the quantitative approach for the treatment, working with simple frequency measurement, that is, identifying the importance of a coding unit by the frequency of its appearance in the documents, using the simple percentage to reveal the results.

For categorization, we used the semantic criteria. The dimensions are empirical variables since they were established from the hypothesis and theoretical study. The categories of analysis were prepared using the procedure per mile (Bardin, 1977), ie, they resulted from the classification of the coding units in the documents, not in the theory. The inference pole was concentrated in the message, focusing on its meanings.

\section{Self-Regulatory Interventions in an Elementary School Context: Results and Discussion}

The research performed in the $8^{\text {th }}$ grade of elementary school, in the English language subject, intended to gradually insert self-regulatory elements through self-assessment activities in their daily classroom routine. The study shows the self-assessment activities performed, focusing on strategic planning and action control, procedures that are part of self-regulatory development.

The first self-assessment intervention in the study focused on the self-reflection phase: from the opportunity to recognize what had been learned, students had to set a goal for remediation. The bold text within the rectangle 
highlights the mechanism used (Figure 1).

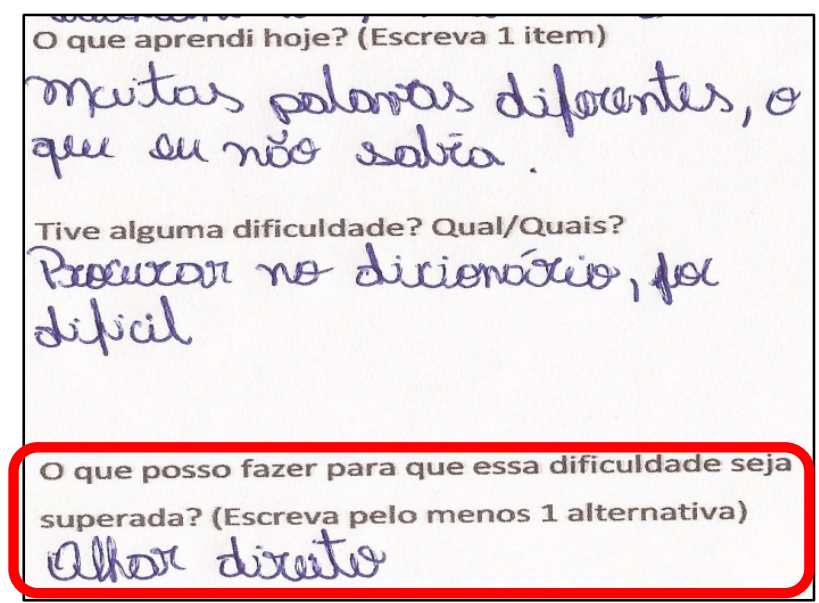

What have I learned today? (Write 1 item)

\section{Many different words, what I}

didn't know.

Did I have any difficulties? Which one/ones?

Looking them up in the dictionary, it was difficult.

What can I do to overcome this difficulty? (Write at least 1

alternative)

Pay more attention when looking them up.

Figure 1. Self-assessment activity 1

However, it was noticed that the activity only provided students with the possibility of setting a specific goal, not totally including the elements which are part of the third phase of the self-regulatory cyclical model. For the successful remediation of a goal, it needs to be turned into an action plan (Sá, 2004), since an adaptive inference is necessary (Zimmerman, 2002). For this purpose, the second self-assessment intervention was performed with the intention of providing students with simple and introductory planning of what to do in order to reach the established goals proposed (Figure 2).
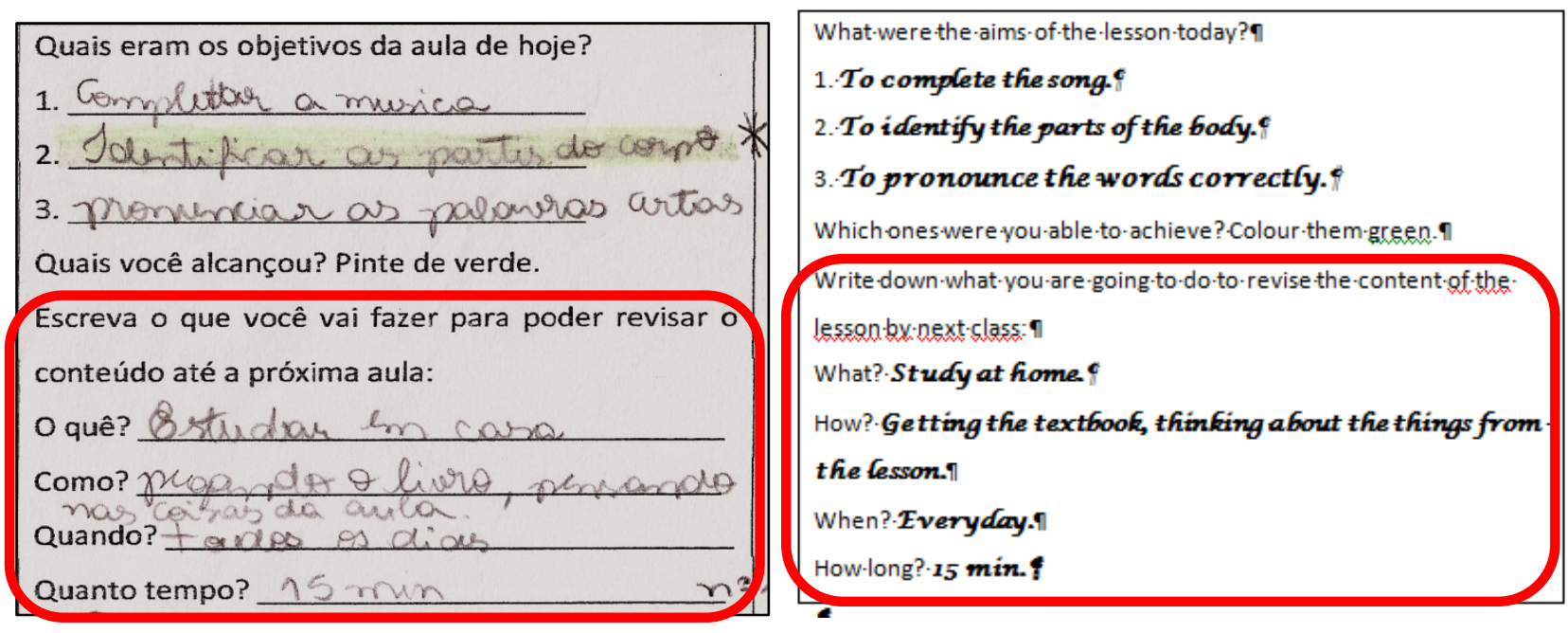

Figure 2. Self-assessment activity 2, performed one week after activity one and two weeks later

In this activity, questions were used in order to make students think of ways to achieve their goals. "What" and "how" questions were intended to encourage them to think of viable strategies, while "when" and "how often" questions were intended to help them to work with volitional control. As the intention was to provide students with adaptive inference, the activity was designed to support strategic planning. However, even with the help of the questions, students had difficulties conceiving ways to remediate the weaknesses found.

The researcher and the teacher had to intervene at this moment, helping students to, firstly, interpret the weakness found and then think of concrete strategies for remediation. They helped the students individually, according to their needs, asking questions that could help them think of a viable alternative for the weakness. Another factor which influenced the intervention in the activity was the worry over the use of metacognition, since part of the process required was to enable awareness of what was involved in their own learning. 
This self-assessment activity, therefore, made some conclusions possible: Firstly, as metacognition is a key element of self-regulated learning development, collaboration with students in recognizing strengths and weaknesses, and undertake strategies (Perry \& Rahim, 2011), would need to be practiced during the period of intervention. Secondly, examples of strategies would need to be available, facilitating the establishment of new goals and planning of the subsequent actions (procedures which are part of the forethought cyclical phase). Thirdly, novice students in the self-regulatory process can make mistakes in the forethought phase (goal setting and strategic planning). Therefore, it is important for the teachers to guide students for the improvement of their learning and performance (Stoeger \& Ziegler, 2011).

These conclusions helped to restructure the following interventions, bearing in mind that the forethought phase should be based on guidance provided by the researcher and the teacher. Strategies are a step taken by the students to approach challenging tasks, selecting from a range of strategies the best ones for the situation to be remediated (Perry \& Rahim, 2011). Thus, some strategic activities were inserted in the lessons, with the intention of promoting knowledge and experimentation of actions that the students themselves would be able to plan in the forethought phase, and execute in the performance/volitional control phase.

Figure 3 shows an example of a strategy that practices memory, used in the classroom with the participants of the study, as the researcher and the teacher had noticed their difficulties in memorizing the vocabulary studied.

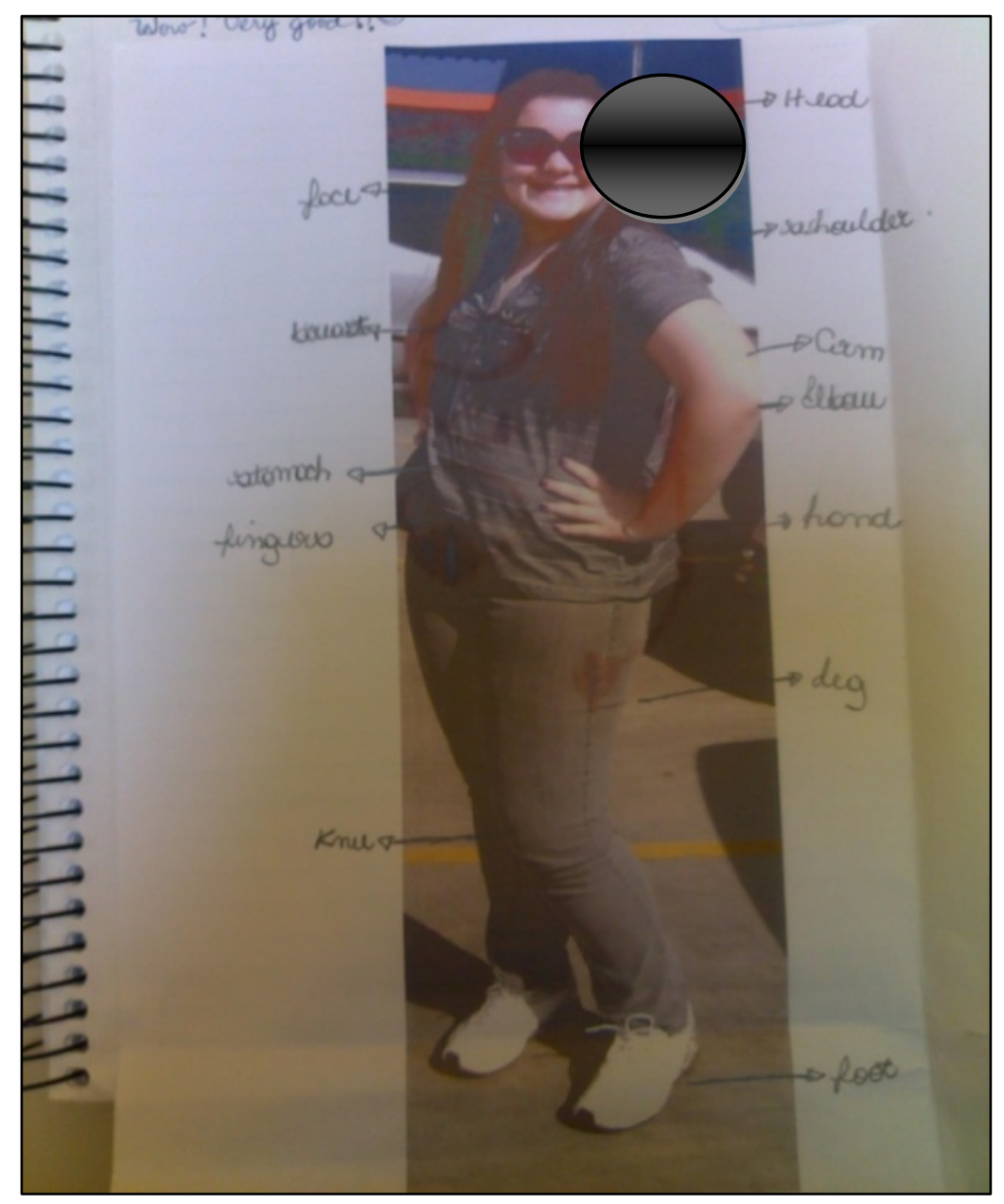

Figure 3. Strategy for memorizing vocabulary

During the fourth self-assessment intervention (Figure 4), after the recognition of strengths and weaknesses using the traffic light icons (Black et al., 2003), students were asked to form groups and spot the difficulties they had in common. Later, the researcher wrote a goal on the blackboard elicited from students' alternatives that could help them reach that goal. The extract from the observation report shows how it happened: 
Firstly, sentences like "study more" and "pay more attention" came out. So, they were asked some questions: "How are you going to study more?", "Why pay more attention?" Then, one of the students said: "Teaching someone". The student was asked: "How?", “Talking”, "How long?", "For one hour". It was explained that it was important to think about specific and practical things as it was done at that moment as a result of the questions asked. Students were helped to set strategies within their groups. As their difficulty was in focusing on specific goals, to find a suitable strategy, they were asked to compare the goals they needed to reach and find those they had in common. In one of the groups, the girls said they had already finished. The strategies were read and questions were asked: "But how are you going to study more?", "I'm going to write the sentences", "What sentences? Where are you going to write them? Are you going to use the book?", "I'm going to use the book", "OK".

\begin{tabular}{|l|l|}
\hline 1. Identificar as partes do corpo. & \\
\hline 2. Identificar os verbos relacionados a acidentes no infinitivo e no passado. & \\
\hline 3. Reconhecer os componentes de um gráfico em inglês. & \\
\hline 4. Escrever as partes do corpo. & \\
\hline 5. Escrever frases no passado utilizando os verbos relacionados a acidentes e às & \\
\hline parte do corpo. & \\
\hline 6. Falar as partes do corpo utilizando a pronúncia correta. & \\
\hline 7. Falar as frases relacionadas a acidentes utilizando a pronúncia correta. & \\
\hline $\begin{array}{l}\text { 8. Elaborar perguntas no passado utilizando o vocabulário estudado (acidentes e } \\
\text { partes do corpo). }\end{array}$ & \\
\hline
\end{tabular}

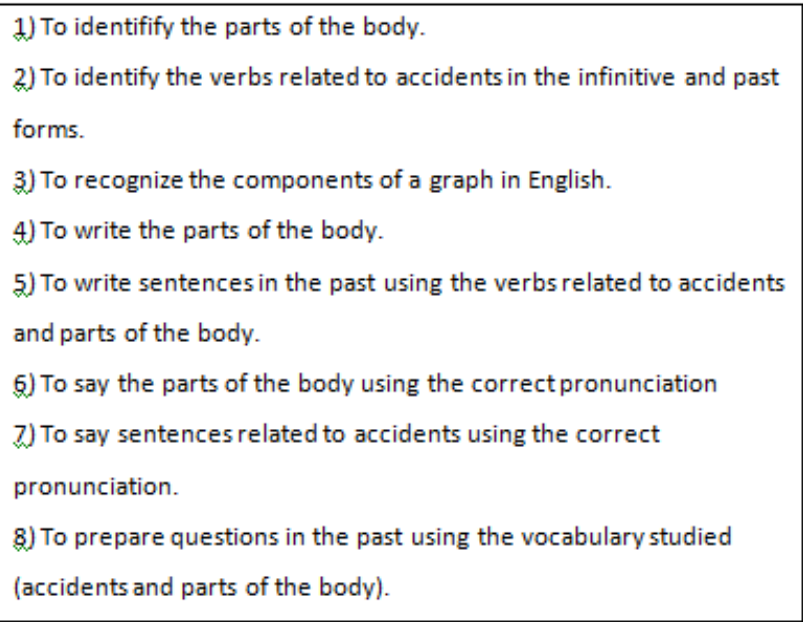

Figure 4. Recognition of strengths and weaknesses using the traffic light icons

After the group work, the students wrote their strategies on sheets of paper. As each evaluated goal in the self-assessment sheet was followed by a number, the researcher wrote the corresponding numbers on the blackboard side by side forming columns, and asked students to stick their strategies on the board, according to the number of the goal. Having all the strategies on the board, the researcher invited the students to select those strategies which could help them overcome the difficulties they had found through the self-assessment sheet (Figure 5).

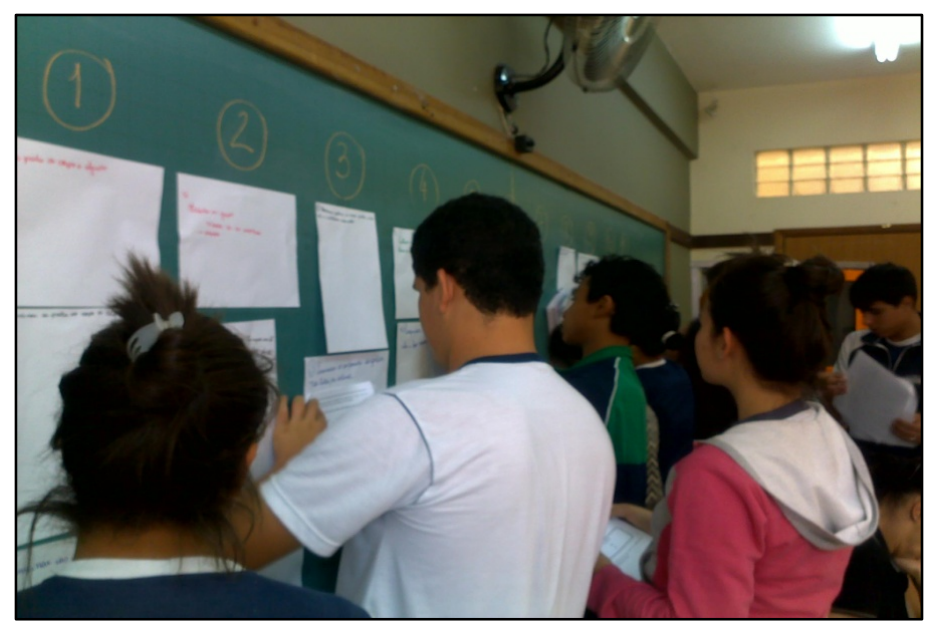

Figure 5. Group activity to select strategies for specific goals 
The selection of strategies was registered in the strategic planning section from the self-assessment sheet (Figure 6). The chosen actions for the specific goals require "skill and will" from the students, which means using cognitive and also motivational skills (Rosário et al., 2005). For this reason, in addition to registering the selected strategies and volitional control, students were asked to choose a prize to reward themselves soon after completion of their tasks. Self-rewards can influence self-reactions, validating perceptions of progress and increasing self-efficacy (Ames, 1990; Schunk \& Zimmerman, 1997).
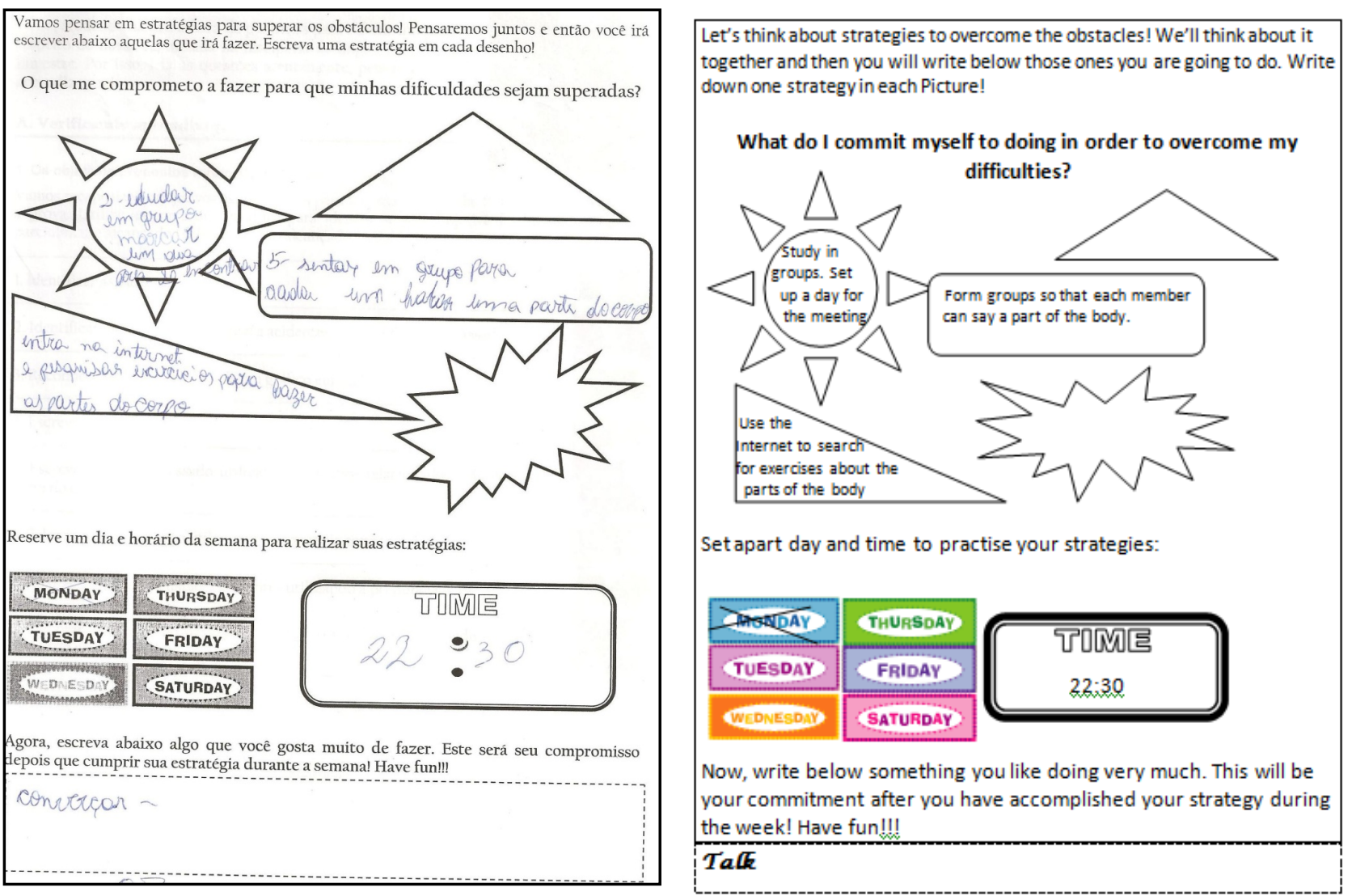

Figure 6. Self-assessment activity 5

This monitoring is part of the second phase of the cyclical model of self-regulation of learning: the performance/volitional control phase (Zimmerman, 2002). For this to happen, two things are essential: self-control and self-observation (Stoeger \& Ziegler, 2011). The use of metacognitive strategies, in addition to volitional, for constant checking of performance, is important here (Zimmerman, 2011). As self-observation is a key element for the implementation of changes (Silva, 2004), some self-assessment activities were conducted during the third bimester so that students could observe the process of the performance/volitional control phase (Figure 7).

At the end of the third bimester, the self-assessment sheets and observation reports were analyzed in order to understand if the students knew what they needed to do to overcome their difficulties. By comparing the difficulties found with the strategic planning of each student, it was found that approximately $43 \%$ of them still had doubts and difficulties in preparing strategic planning. Furthermore, by controlling the self-monitoring activities, it was found that most students did not perform what they had committed to do or performed only a portion of what had been planned (Figure 8).

Given these results, students were asked to write on a card the possible reasons for non-compliance of the tasks and the strategic planning. The responses revealed that $94 \%$ of students were aware of what hindered them from performing the tasks. Forgetfulness was the reason with the highest incidence.

Laziness and also because I do not like to study. (STUDENT 3).

Because I didn't have the will or interest. (STUDENT 12). 
A bit because of forgetfulness and a bit because of irresponsibility. (STUDENT 20).

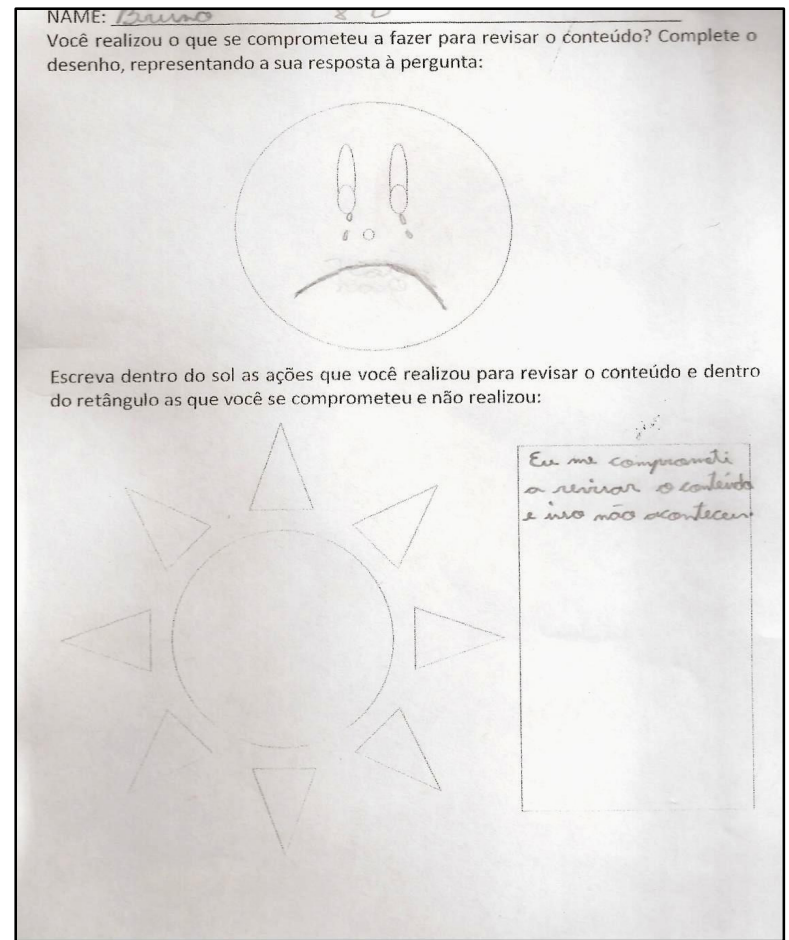

1. Fiz todas as tarefas propostas? mem toodar

2. Se deixei tarefas sem fazer, por que isto aconteceu? _las̃ tinho tempo bu porqus en mós sabra

3. Participei das aulas, procurando entender o conteúdo? Sem

Se não, por quê?

4. Mantive o meu caderno organizado? naw

5. Procurei organizar o meu local de estudo? sim

6. Reservei um tempo na minha semana para estudar inglês? mố

7. Procurei ajuda da professora ou dos colegas quando precisei? Stm

8. Há objetivos a serem revistos e alcançados? Jom tolot

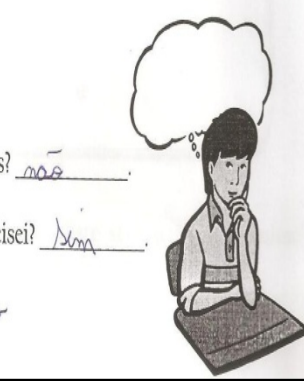

NAME:

Did you do what you had commited yourself to doing in order to revise the content? Complete the picture, representing your answer to the question:

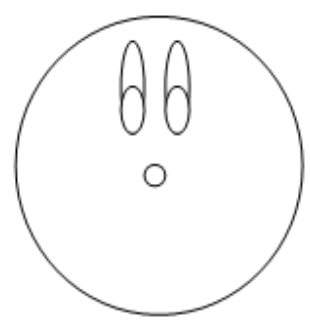

Write inside the Sun the actions you accomplished to revise the content, and inside the rectangle the ones you had commited yourself to doing but didn't do:

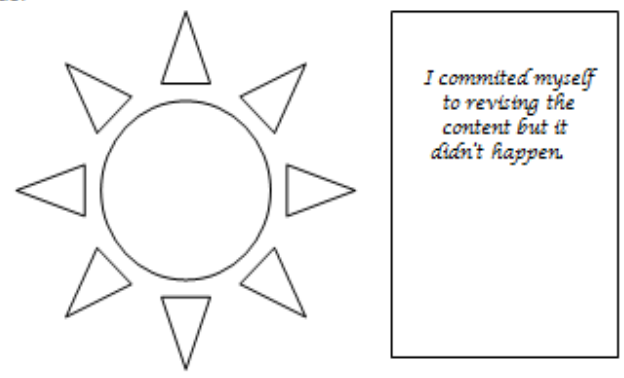

1. Did I do the homework proposed? Not all

2. If I left homework undone, why did it happen? I didn't fiave time or Gecause I didn't know fow to do it.

3. Did I participate in the lessons, trying to understand the content? If not, why? $\mathrm{yes}$.

4. Did I keep my notebook organized? $\mathcal{N}$ o.

5. Did I try to organize the place where I study? $\mathbf{y}$ es.

6. Did I set apart some time during the week to study English? $\mathcal{N}$.

7. Did I look for the help of my teacher and classmates when I needed? yes.

8. Are there goals to be reviewed and achieved? Not all.

Figure 7. Examples of activities that facilitate the process of self-observation, performed during the third bimester of 2011 


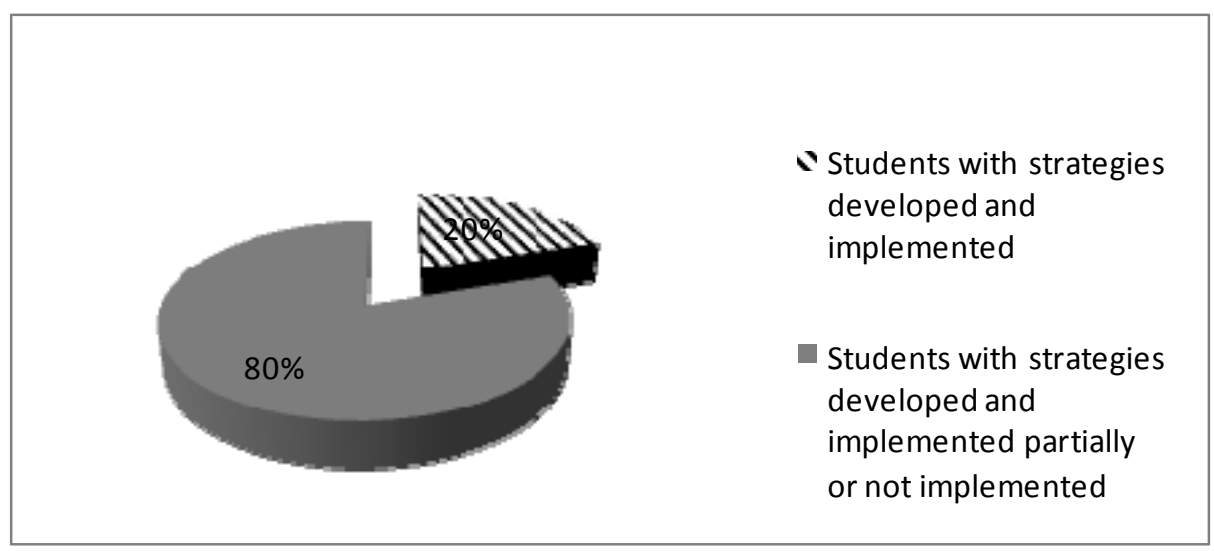

Figure 8. Performance of the strategic planning on the third bimester

Analyzing the activities with students during the third bimester, it was noticed that there was a need to guide actions related to the forethought phase - strategic planning and self-motivation beliefs - and the performance/volitional control phase - self-control - more punctually. Consequently, volitional processes (control of attention, emotional control and learning environment control) would be employed and encouraged, in order to reduce distractive elements (Silva, 2004). These processes help students to concentrate so that they can protect intentions related to their goals (Zimmerman, 2011). For this, the learning conditions of students were investigated.

The researcher already had data on the learning environment of students, a factor which was examined in the third bimester. According to students' reports, approximately $72 \%$ of them said they had favorable environment for studying at home. This data was collected based on what is proposed by Figueiredo (2008) for regulatory responsibilities of the physical environment. As one of several self-regulatory strategies (Zimmerman \& Martinez-Pons, 1986), structuring the learning environment outside the classroom does not have a specific rule, but needs to make the student eliminate, as best as possible, the distractions, and also make sure they have favorable space to concentrate and perform the tasks. The environment can influence behavior, as behaviour can also influence the environment (Schunk \& Zimmerman, 1997). Therefore, individuals may use more mental concentration in an environment full of distractions, or optimize that environment to make it a support for performing tasks. Those students who reported not having a favorable environment, thought about alternatives to optimize their study space. However, the aim was not only to allow them to carry out the strategy correctly, but also to understand why it would be helpful, through the analysis of their own learning environment and what would help or disrupt the performance of the task, thus adopting a strategic knowledge (Veiga Simão, 2004).

No more watching TV at study time. (STUDENT 20).

Always do homework in quiet places. (STUDENT 17).

The place where I do homework is not bad, but sometimes I watch TV or listen to music doing homework, however I will try not to do this anymore. (STUDENT 2).

Another sheet for investigation was made available to students in order to collect information about the performance of tasks, time management, engagement in studying, and students' perception of teachers' reactions in relation to studies and tasks. The sample shows that $38 \%$ of students set apart some time to study during the week, an integral part of the performance/volitional control phase. The planning of study schedules helps them to develop self-regulatory skills, avoiding concentration difficulties due to lack of time, anxiety and insecurity, as well as intense study on the eve of a test (Figueiredo, 2008). Therefore, this is an aspect that should be taken into account when conducting the activities in the fourth bimester. The reasons for the lack of studies had a higher incidence of forgetfulness ( $48 \%$ ), followed by chores at home (28\%).

Another factor that deserves attention in the research is the encouragement received to study. According to the analysis of the sheet filled in by the students, $92 \%$ receive encouragement at home to carry out their studies, with parents being the ones who provide the most encouragement. Parents, older siblings and friends may be helpers to self-regulated learning (Rosário et al., 2005, 2012). The family contributes to emotional stability and can provide various support resources, such as demonstrating appreciation of effort and involvement in school life. The testimony of one student at the end of the intervention period draws attention to the use of time management and parental support in the process: 
Oh, [the strategies] helped me to, like, prepare more, study more, like, avoid not having enough time for studying. Studying more times a day, increasing the time, not worrying about, like, using the computer, these things. I set apart, like, two hours a day. Well, it's not so much for me because I don't have a job and I don't help at home, so my mother says: no, you have to study, , because if you don't study, you won't get anywhere. (STUDENT 25).

However, despite the importance of the assistance of parents in the development of self-regulatory skills, many of them do not have availability or competence to monitor their children (Rosário et al., 2012). This gets worse when they are "negative models, when showing that they attribute greater value to grades or diplomas, or when parents show no interest in the school lives of their children." (Bzuneck, 2010, p. 13). Most participants of the study revealed having no problems with family encouragement to study, also indicating that they are helped in school tasks at home (74.19\%), with parents the primary support (approximately $42 \%$ ).

Another factor investigated was the perceived reactions of teachers (teacher and researcher) regarding completion of homework. Through the reading of the sheets, there was a higher incidence in the role of teachers as demanding (Figure 9).

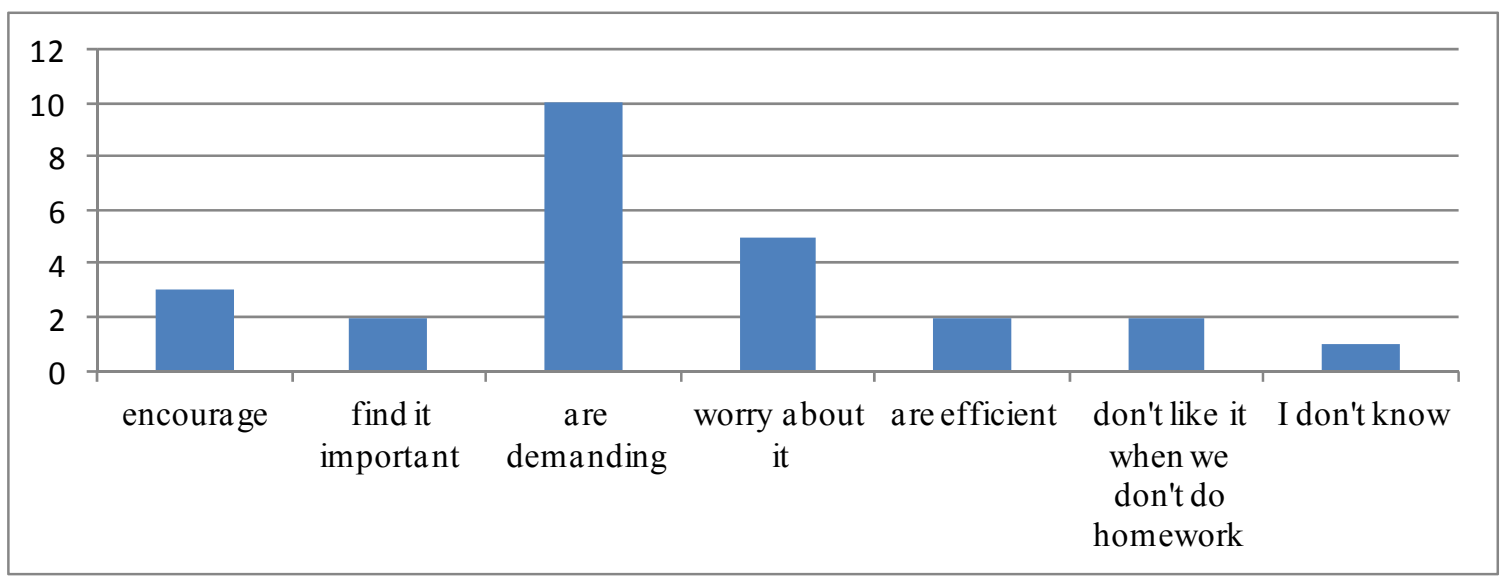

Figure 9. Perceived reactions of teachers regarding completion of homework

With the exception of an "I don't know" response, it was observed that students perceive that teachers care about their studies beyond the classroom. This role is considered important for the development of self-regulatory skills in students (Rosário, 2001; Rosário et al., 2005; Zimmerman, 2002), since "educators should consider the extent to which educational interaction (people responsible for education, teachers...) favors the appearance of this behavioral profile invested in the task. "(Rosário et al., 2006, p. 82).

The results of the sheet for investigation led to some conclusions: (1) most of the class revealed favourable environment conditions for studying, (2) however, only approximately one third, set apart some time every week for studying outside classroom, (3) most students have encouragement at home to study and support for the completion of homework, (4) almost $100 \%$ of them realize that the teachers care about homework completion. However, a lack of commitment to the implementation of activities outside the classroom was commonplace.

A partial implementation or non-implementation of the strategic planning could therefore be tied, to the difficulty found by students in its preparation, causing a failure to implement the strategies chosen. Another factor that may have influenced the results is the lack of motivation to learn the language. The motivated individual guides their actions by having expectations of results (Azzi \& Polydoro, 2010). Moreover, the belief in the effectiveness of the performance of an activity translates into the thought of having the ability to do something or not. According to the participants' teacher, their difficulties with the subject already existed in the first half of 2011, which is revealed by low grades, and a lack of interest in their studies as a result. In this context, outcome expectations and self-efficacy beliefs of these students could be low, causing the lack of effort to undertake actions that would help them overcome what they haven't learned. Another issue to be highlighted is the number of distractions available to young people nowadays, which may disrupt their dedication and responsibility to homework.

The demonstration, only, of the importance of learning the content offered at school was not enough. Besides enhancing the learning process and the improvement of skills, they must also have the will to employ efforts to 
develop and apply their knowledge and skills in order to develop a long-term commitment to learning (Ames, 1990). Therefore, besides using the self-assessment sheets, activities that had a more challenging approach were included in the interventional planning in the research, provoking the students' interest with "motivational factors (Note 2)". Four were chosen to give continuity to the activities from the research in the fourth bimester: novelties, cognitive conflict, food and games (Bergin, 1999).

The proposal was to introduce different tasks every week, with the intention of provoking more interest in its realization, intertwined with the performance of self-assessment activities to keep them aware of their progress and their difficulties, increasing the capacity for reflection about their own learning situation. After all, the goal was to help them understand their own steps and undertake actions for remediation and improvement, based on self-assessment. But for that, they would have to be motivated for the implementation of their strategic planning, a fact that was not happening for most students. Furthermore, volitional processes should be taught and exemplified.

Task sheets were prepared with the intention of combining cognitive conflict and novelties (factors that influence interest) with time management and examples of strategies to be used to study (self-control). Doing homework at home is essential to promote learning, resulting in its higher quality. "The establishment of good study habits, organization and time management, personal accountability, promotion of autonomy and self-regulatory control are examples of goals the homework intends to achieve." (Rosário et al., 2005, p. 344).

For every homework task done, students would receive, in the following class, a reward, in the form of candies and chocolate, representing another type of motivational factor. It is assumed that food attracts interest above and beyond any effect of novelty (Bergin, 1999). In this case, food corroborates the motivation to perform the following pieces of homework.

Another method used to attract the interest of students, which is considered successful (Bergin, 1999), was the use of games. A competition was organized soon after the first test for the revision of students' difficulties, and a quiz show at the end of the semester, offering integration with the other $8^{\text {th }}$ grade classes. Students were informed in advance of the two games through posters in the classroom and announcements carried out by the researcher and the teacher. In addition, students were asked to do some activities at home using the textbook to prepare for the games. They organized themselves into small groups in order to study together, preparing for the games. These were well received by the students, as recorded in the observation report:

At break time, on the day of the competition, some students remained in the room and others even arrived early to ask what we would do in the game (in all lessons observed previously, students never arrived punctually in class, tardiness was constant). Surprisingly, they asked IF help was needed to organize the room. It was accepted, then eight of them assisted in the arrangement of desks and posters for the beginning of the competition. All students, except one (who was on the phone), participated in the activities and were competitive (screamed, cheered).

These added factors are useful when they are motivational and challenging, and besides being fun/interesting, make students think, supporting learning goals (Bzuneck, 2010). The competition and the quiz show were new to that class and were considered tools of interest and engagement to study, resulting in greater effort to carry out the homework (Figure 10).

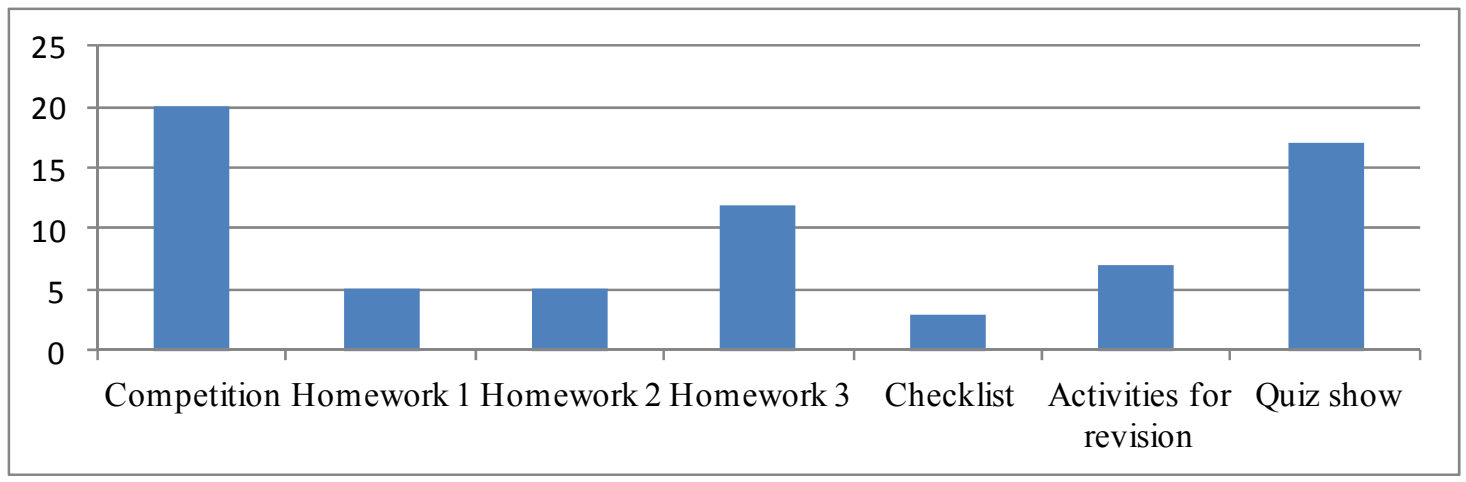

Figure 10. Studying at home through the required tasks 
The games were the ones that had the greatest impact in relation to studies at home, a factor that was observed by the researcher and the teacher when checking if students had done the homework and how they had done it. It is assumed that the motivation for the game turned into an intention to act (Boekaerts \& Corno, 2005), causing intense study and participation in these activities.

The guidelines offered by the researcher and the teacher for the homework aimed at providing more self-regulatory development, offering auxiliary tools to accomplish tasks more efficiently (Rosário, 2001) and, consequently, with more autonomy.

The accomplishments of the tasks and studies were recorded, as well as the comments from the students with respect to their performance. The analysis confirmed a significant improvement in students' commitment to studying, revealing a 20\% increase compared to the third bimester (Figure 11).

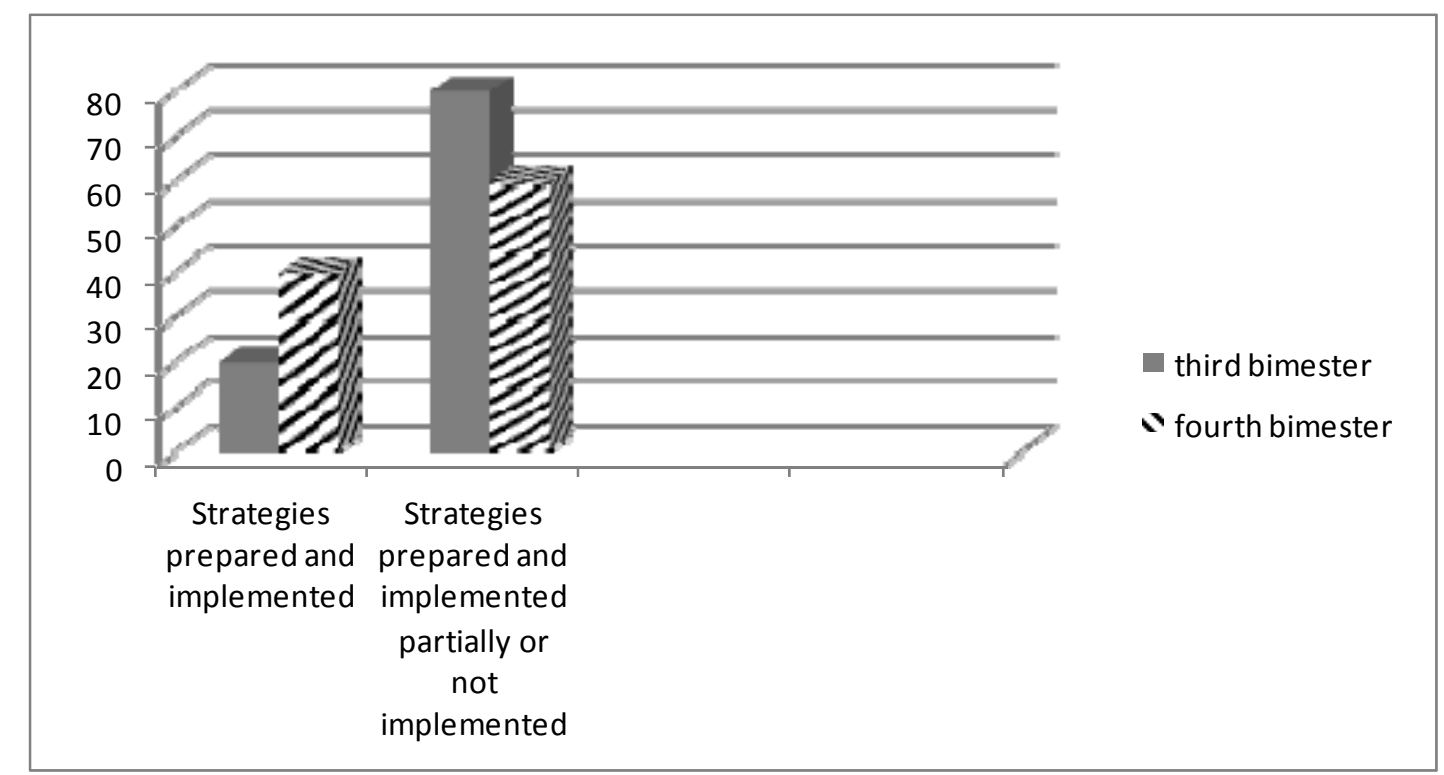

Figure 11. Performance of the strategic planning on the fourth bimester, compared to the third bimester (percentage)

The responses to questionnaires and interviews highlight that 21 students $(84 \%)$ perceived changes in their studies over the semester of interventions.

Ah, it changed because now, sometimes, I always get, like, the notebook to have a look, not only in the English language subject, but also in the others. Before that I didn't put much effort to it, you know, so today I think I'm more focused. (STUDENT 3).

Yes, because in the past I didn't use to study at home, and at school I only studied for the tests. Now I study at home and at school. (STUDENT 5).

I felt freer, much freer to do the activities, knowing a lot more things. Before, I didn't know much and kept quiet, wasn't open to doing things. (STUDENT 9).

They didn't change much, but, you know, I think that they helped us to study, encouraged us, you know what I mean? I think it was cool. But it didn't change much because I was already used to studying a bit. (STUDENT 21).

Another factor that drew the attention was the perception of the use of strategies. Twelve students (48\%) revealed that strategies are important because they encourage/facilitate studying, and seven (28\%) recommended the use of strategies as a mechanism to learn more. It was observed that a large number of students had greater development in the forethought and the performance/volitional control phase during the fourth bimester, increasing the rate of commitment in relation to the third bimester.

\section{Conclusion}

The reports reveal that the intervention process caused improvements, a result that would not have been possible 
if there had been no influence of some factors, such as the encouragement of the teachers, the environment prepared for the phases of self-regulation and the actions of the students themselves, based on the use of self-assessment activities, a support for triggering self-regulatory actions.

The study allowed us to understand the use of self-assessment activities as a palpable, concrete support, to be used by the teacher to undertake self-regulatory practices with students. The main intention was to make these students develop study habits inside and outside the classroom, increasing autonomy and responsibility for their own learning. However, to make this possible, it was necessary to use methods that could help them develop the habit of looking at their own performance, making this action a constant exercise for the improvement of learning. The self-assessment practice presents as its main feature a stimulus for the recognition of learning and the planning of intervention actions. In the study, this practice has worked as a conductor of the actions from the cyclical model for self-regulation, which allowed students to: (1) recognize their strengths and weaknesses, (2) reflect on the reasons for their difficulties, (3) design a strategic plan; (4) monitor the plan and (5) analyze the results of the plan.

However, the study also found that achieving the self-regulatory cycle depended on the teacher's intervention. Mediation was necessary all the time, according to the students' needs in each step of the cycle. The development of greater autonomy was conditional upon the guidance of a mediator, who guided students through the steps to be undertaken at each step throughout the cycle.

Moreover, it was also found that the recognition of one's own performance and the preparation of a strategic plan, alone, do not lead to the realization of the plan. The motivational factor had considerable influence at this stage. Therefore, it is assumed that motivational factors and the use of rewards were the bridge between motivation and the acquisition of study habits for those who were, for the first time, learning to monitor their own learning.

The self-assessment practice has the potential for the development of self-regulation because of the inherent features in its concept, as well as the possibility of making these features palpable to students. However, it will only have a self-regulatory effect if combined with the intervention of a teacher who conducts the self-regulation cycle and works with teaching of strategies, along with activities related to motivational factors and rewards, at least at the beginning of a process of autonomy development in the classroom.

For future studies, self-assessment activities, based on the cyclical model of self-regulation, could be applied and observed for a longer period of time in order to check if motivational factors continue to be a constant variable or if they could be discarded. Also, the same study could be applied to students who are in the 5th grade (10-11 years old), when children recognize the importance of learning and, at the same time, start becoming less intrinsic motivated to study. The practice of self-regulation in this group could be observed in order to check if it would influence students' learning and motivation positively.

\section{References}

Ames, C. A. (1990). Motivation: what teachers need to know. Teachers College Record, 91(3), 409-421.

Azzi, R. G., \& Polydoro, S. A. J. (2010). O papel da autoeficácia e autorregulação no processo motivacional. In E. Boruchovitch, J. A. Bzuneck, \& S. E. R. Guimarães (Eds.), Motivação para aprender: Aplicações no contexto educativo (pp. 126-144). Petrópolis, RJ: Vozes.

Bardin, L. (1977). Análise de conteúdo. Lisboa: Edições 70.

Bergin, D. A. (1999). Influences on classroom interest. Educational Psychologist, 34(2), 87-98. http://dx.doi.org/10.1207/s15326985ep3402_2

Black, P., Harrison, C., Lee, C., Marshall, B., \& Wiliam, D. (2003). Assessment for learning: Putting it into practice. Berkshire: Open University Press.

Boekaerts, M., \& Corno, L. (2005). Self-regulation in the classroom: A perspective on assessment and intervention. Applied Psychology: An International Review, 54(2), 199-231. http://dx.doi.org/10.1111/j.1464-0597.2005.00205.x

Boud, D. (1995). Enhancing Learning through self assessment. Oxon: RoutledgeFalmer.

Butler, Y. G., \& Lee, J. (2010, January). The effects of self-assessment among young learners of English. Language Testing, 27, 5-31. http://dx.doi.org/10.1177/0265532209346370

Bzuneck, J. A. Como motivar os alunos: Sugestões práticas. (2010). In E. Boruchovitch, J. A. Bzuneck, \& S. E. R. Guimarães (Eds.), Motivação para aprender: Aplicações no contexto educativo (pp. 13-42). Petrópolis, RJ: Vozes. 
Cohen, A. D. (1998). Strategies in learning and using a second language. Harlow, Essex: Addison Wesley Longman Limited.

Duarte, A. M. Auto-regulação e abordagens à aprendizagem. (2004). In A. L. Silva, A. M. Duarte, I. Sá, \& A. M. Veiga Simão (Eds.), Aprendizagem auto-regulada pelo estudante: Perspectivas psicológicas e educacionais. Porto: Porto Editora.

Figueiredo, F. J. C. (2008, April). Como ajudar os alunos a estudar e a pensar? Auto-regulação da aprendizagem. Millenium, 34, 233-258.

Flick, U. (2004). Uma introdução à pesquisa qualitativa. São Paulo: Artmed.

Freire, L. G. L. (2009). Auto-regulação da aprendizagem. Ciência \& Cognição, 14(2), 276-286.

Harris, M. (1997). Self-assessment of language learning in formal settings. ELT Journal, Oxford, 51(1), 12-20. http://dx.doi.org/10.1093/elt/51.1.12

Little, D. (1996). Strategic competence considered in relation to strategic control of the language learning process. In D. Little, \& H. HOLEC (Eds.), Strategies in language leraning and use: Studies towards a common european framework of reference for language learning and teaching. Council of Europe Publishing. Education committee. (pp. 12-25). Council for cultural co-operation.

Mistar, Junaidi. (2011). A study of the validity and reliability of self-assessment. TEFLIN Journal, Malang, 22(1), $1-10$.

Nunan, D. (2005). Research Methods in Language Learning. New York: Cambridge University Press.

Paris, S. G., \& Paris, A H. (2001). Classroom applications of research on self-regulated learning. Educational Psychologist, 36(2), 89-101. http://dx.doi.org/10.1207/S15326985EP3602_4

Perry, N. E., \& Rahim, A. (2011). Studying self-regulated learning in classrooms. In B. J. Zimmerman, \& D. H. Schunk (Eds.), Handbook of self-regulation of learning and performance (pp. 122-136). Educational Psychology Handbook Series. New York: Routledge.

Rosário, P. (2001). Diferenças processuais na aprendizagem: Avaliação alternativa das estratégias de auto-regulação da aprendizagem. Psicologia, Educação e Cultura, 5, 87-102.

Rosário, P., Mourão, R., Salgado, A., Rodrigues, Â., Silva, C., Marques, C., Amorim, L., Machado, S., Núñez, J. C., Gonzáles-Pienda, J., \& Pina, F. H. (2006). Trabalhar e estudar sob a lente dos processos e estratégias de auto-regulação da aprendizagem. Psicologia, Educação e Cultura, 10, 77-88.

Rosário, P., Mourão, R., Soares, S., Chaleta, E., Grácio, L., Simões, F., Núñez, J. C., \& Gonzáles-Pienda, J. A. (2005). (September-December). Trabalho de casa, tarefas escolares, auto-regulação e envolvimento parental. Psicologia em Estudo, 10(3), 343-351. http://dx.doi.org/10.1590/S1413-73722005000300002

Sá, Isabel. (2004). Os componentes motivacionais da aprendizagem auto-regulada: A autodeterminação e a orientação para objetivos. In A. L. Silva, A. M. Duarte, I. Sá, \& A. M. Veiga Simão (Eds.), Aprendizagem auto-regulada pelo estudante: perspectivas psicológicas e educacionais. Porto: Porto Editora.

Schunk, D. H., \& Zimmerman, B. J. (1997) Social origins of self-regulatory competence. Educational Psychologist, 32, 195-208. http://dx.doi.org/10.1207/s15326985ep3204_1

Silva, A. L. (2004). A auto-regulação na aprendizagem: a demarcação de um campo de estudo e de intervenção. In A. L. Silva, A. M. Duarte, I. Sá, \& A. M. Veiga Simão (Eds.), Aprendizagem auto-regulada pelo estudante: Perspectivas psicológicas e educacionais. Porto: Porto Editora.

Souza, N. A., \& Boruchovitch, E. (2009, October). Avaliação da aprendizagem e motivação para aprender: tramas e entrelaços na formação de professores. Educação Temática Digital, 10, 204-227.

Stoeger, H., \& Ziegler, A. (2011). Self-regulatory training through elementary-school students' homework completion. In B. J. Zimmerman, \& D. H. Schunk, Handbook of self-regulation of learning and performance (pp. 87-101). New York: Routledge.

Veiga Simão, A. M. (2004). O conhecimento estratégico e a auto-regulação da aprendizagem: implicações em contexto escolar. In A. L. Silva, A. M. Duarte, I. Sá, \& A. M. Veiga Simão (Eds.), Aprendizagem auto-regulada pelo estudante: Perspectivas psicológicas e educacionais. Porto: Porto Editora.

$\mathrm{Xu}$, J. (2009). School location, student achievement, and homework management reported by middle school students. The School Community Journal, 19(2), 27-43. 
Zimmerman, B. J. (1989). A social cognitive view of self-regulated academic learning. Journal of Educational Psychology, 81(3), 329-339. http://dx.doi.org/10.1037/0022-0663.81.3.329

Zimmerman, B. J. (2002). Becoming a self-regulated learner: An overview. Theory Into Practice, 41(2), 64-70. http://dx.doi.org/10.1207/s15430421tip4102_2

Zimmerman, B. J. (2011). Motivational sources and outcomes of self-regulated learning and performance. In B. J. Zimmerman, \& D. H. Schunk (Eds.), Handbook of self-regulation of learning and performance (pp. 49-60). New York: Routledge.

Zimmerman, B. J., \& Cleary, T. J. (2004). Self-regulation empowerment program: A school-based program to enhance self-regulated and self-motivated cycles of student learning. Psychology in the Schools, 41(5), 537-550. http://dx.doi.org/10.1002/pits.10177

Zimmerman, B. J., \& Martinez-Pons, M. (1986). Development of a structured interview for assessing student use of self-regulated learning strategies. American Educational Research Journal, 23, 614-628. http://dx.doi.org/10.3102/00028312023004614

Zimmerman, B. J., Bandura, A., \& Martinez-Pons, M. (1992). Self-motivation for academic attainment: The role of self-efficacy beliefs and personal goal setting. American Educational Research Journal, 29(3), 663-676. http://dx.doi.org/10.3102/00028312029003663

\section{Notes}

Note 1. Trabalhos de casa, aprendizagem autorregulada e rendimento acadêmico: dilucidar quês e porquês na disciplina de inglês como língua estrangeira, written by Pedro Rosário and cols., to be edited by EDUEL, 2012.

Note 2. Embelezamentos motivacionais.

\section{Copyrights}

Copyright for this article is retained by the author(s), with first publication rights granted to the journal.

This is an open-access article distributed under the terms and conditions of the Creative Commons Attribution license (http://creativecommons.org/licenses/by/3.0/). 